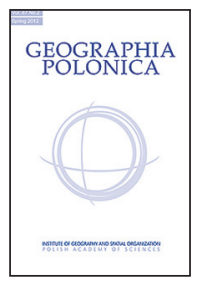 \\ INSTITUTE OF GEOGRAPHY AND SPATIAL ORGANIZATION \\ POLISH ACADEMY OF SCIENCES \\ www.igipz.pan.pl \\ www.geographiapolonica.pl
}

\title{
FACTORS INHIBITING CONVECTION UNDER CONDITIONS OF EXTREME ATMOSPHERIC INSTABILITY
}

\author{
Angelika Palarz • Daniel Celiński-Mysław \\ Department of Climatology \\ Jagiellonian University \\ Gronostajowa 7, 30-387 Kraków: Poland \\ e-mails: angelika.palarz@doctoral.uj.edu.pl • daniel.celinski-myslaw@doctoral.uj.edu.pl
}

\begin{abstract}
The paper identifies mechanisms that potentially inhibit convection at a time when extreme values of selected atmospheric instability indices are recorded. The study involved six indices (LI, SI, CAPE, KI, SWEAT, TII). Data sources involved records from three Polish data stations collecting upper air soundings and covered the period 2005-2014. Additional data were obtained from SYNOP codes on present and past weather and reports on severe meteorological phenomena from the European Severe Weather Database. The methodology adopted allowed the selection of 26 cases where no convective phenomena were observed despite extreme atmospheric instability. A detailed analysis demonstrated that the occurrence of isothermal or inversion layers in the lower and middle troposphere were the most frequent mechanisms inhibiting the vertical air movement. Convection was also inhibited when the area was free from the influence of atmospheric fronts, convergence zones, lowpressure troughs or when high altitudes of $\mathrm{LCL}$ occurred.
\end{abstract}

\section{Key words}

convection inhibition $\bullet$ atmospheric instability indices $•$ Poland $\bullet$ upper air sounding

\section{Introduction}

Atmospheric instability indices are popular in forecasting powerful convective phenomena. Their verifiability, however, can be strongly affected by the occurrence of a range of factors inhibiting the development of the vertical movement of air. Published research on the temporal and spatial variability of instability indices used either upper air sounding data
(DeRubertis 2006; Venkat Ratnam et al. 2013), or climatological reanalyses (Brooks et al. 2007; Riemann-Campe et al. 2009). These studies primarily involved the indices most frequently used in synoptic practices, i.e. Convective Available Potential Energy (CAPE) and Convective Inhibition (CIN) (Blanchard 1998; Romero et al. 2007; Brooks 2009; RiemannCampe et al. 2009). The other indices, including the Lifted Index (LI), Severe Weather Threat 
Index (SWEAT), Showalter Index (SI), K-Index (KI) and Total Totals Index (TTI) featured in far fewer studies (Siedlecki 2009; Venkat Ratnam et al. 2013).

The relationship between the values of atmospheric instability indices and the occurrence of convective phenomena has been studied with regards to thunderstorms (Sanchez et al. 2009; Gubenko \& Rubinshtein 2015), hailstorms (Palencia et al. 2010; Hand \& Cappelutti 2011) and tornadoes (Brooks et al. 2003; Romero et al. 2007). These studies identified a number of threshold values (with wide spatial variation), the crossing of which could lead to severe weather events. They also demonstrated that powerful convective phenomena could develop in relatively low instability environments. Such occurrences involve high kinematic parameters (e.g. strong wind shears) which are mostly observed during the cool half of the year (Bentley \& Mote 2000; Burke \& Schultz 2004; Van den Broeke et al. 2005; Sherburn \& Parker 2014).

Major factors known to help the development of convection include unstable atmosphere, a low lifting condensation level, a large concentration of water vapour in the lower troposphere and large scale mechanisms assisting in the development of convection (e.g. fronts, convergence lines and low-pressure troughs). Also kinematic and thermodynamic conditions play a significant role. There is a certain body of research available in this area, including studies on the impact of Convective Inhibition $(\mathrm{CIN})$ and of the Lifting Condensation Level (LCL) on the occurrence of powerful convective events which were presented by Chaboureau et al. (2004) and Davies (2004). A number of authors, including Chaboureau et al. (2004), Wong and Dessler (2005) and Riemann-Campe et al. (2009), to name but a few, wrote about the inhibitive role of isothermal and inversion layers in the development of upward air movement.

This study builds on the previous research on the inhibition of vertical air movement in the lower troposphere. Its overall objective is to identify mechanisms leading to the inhibition of the development of convection under conditions of extreme atmospheric instability.

\section{Materials and methods}

The study employed upper air sounding data from the database of the University of Wyoming's Department of Atmospheric Science (http://weather.uwyo.edu/). This included the values of the six indices most frequently applied in convection forecasting: CAPE (Convective Available Potential Energy), LI (Lifted Index), SI (Showalter Index), KI (K Index), SWEAT (Severe Weather Threat Index), TTI (Total Totals Index). Data from three Polish stations (Legionowo, Łeba and Wrocław), as taken at 12:00 UTC during the period 2005-2014 were used in this paper. Extreme values of the atmospheric instability indices were defined using their probability of occurrence: below the $5^{\text {th }}$ percentile for $\mathrm{LI}$ and $\mathrm{SI}$ and above the $95^{\text {th }}$ percentile for CAPE, KI, SWEAT and TTI. The analysis was then restricted to just those cases in which at least three of the six indices met the cutoff conditions.

CAPE is an amount of energy that is available during convection, and is calculated by integrating vertically the local buoyancy of the parcel from the level of free convection (LFC) to equilibrium level (EL). The formal definition is given by (Moncrieff \& Miller 1976):

$$
C A P E=\int_{L F C}^{E L} g\left(\frac{T_{v p}-T_{v e}}{T_{v e}}\right) d z[J / k g]
$$

where:

$g$ - is the acceleration due to gravity,

$T_{v p}$ - is the virtual temperature of the parcel,

$T_{v e}$ - is the virtual temperature of the environment.

To the investigation of the weather conditions in selected cases, the energy available to a parcel of air originating at the surface and being lifted to its level of free convection (SBCAPE - Surface-Based Convective Available Potential Energy) and the energy of strong downdrafts (DCAPE - Downdraft) were used. 
$\mathrm{LI}$ is the temperature difference between the environment temperature at $500 \mathrm{hPa}$ $\left(\mathrm{T}_{\mathrm{e} 500}\right)$ and the temperature of a parcel lifted adiabatically to $500 \mathrm{hPa}\left(\mathrm{T}_{\mathrm{p} \text { Surface } \rightarrow 500}\right)$, given by (Galway 1956):

$$
\mathrm{LI}=\mathrm{T}_{\text {e } 500}-\mathrm{T}_{\text {psurface } \rightarrow 500}\left[{ }^{\circ} \mathrm{C}\right]
$$

Lifting parcel from the surface is done in order to capture low level boundary layer temperature and moisture conditions while reducing diurnal effects.

$\mathrm{SI}$ is defined as the difference between the observed temperature at $500 \mathrm{hPa}\left(\mathrm{T}_{\text {e500 }}\right)$ and the temperature of an air parcel after it has been lifted adiabatically to $500 \mathrm{hPa}$ from $850 \mathrm{hPa}\left(\mathrm{T}_{\mathrm{p} 850 \rightarrow 500}\right)($ Showalter 1953):

$$
\mathrm{SI}=\mathrm{T}_{\mathrm{e} 500}-\mathrm{T}_{\mathrm{p} 850 \rightarrow 500}\left[{ }^{\circ} \mathrm{C}\right]
$$

In the case of SI an air parcel is lifted from $850 \mathrm{hPa}$ where localized low level influences are greatly reduced.

Total Totals Index is expressed as the temperature difference between $850\left(T_{850}\right)$ and $500 \mathrm{hPa}\left(\mathrm{T}_{500}\right)$ and the difference between dew point at $850 \mathrm{hPa}$ level $\left(\mathrm{T}_{\mathrm{d} 850}\right)$ and the temperature at $500 \mathrm{hPa}$ (Miller 1972):

$$
\Pi \mathrm{I}=\left(\mathrm{T}_{850}-\mathrm{T}_{500}\right)+\left(\mathrm{T}_{\mathrm{d} 850}-\mathrm{T}_{500}\right)\left[{ }^{\circ} \mathrm{C}\right]
$$

K-Index is s similar to Total Totals Index. Additionally this index takes into account moist air at $700 \mathrm{hPa}$ contributing to air mass thunderstorms development. $\mathrm{KI}$ increases with decreasing static stability between 850 and $500 \mathrm{hPa}$, increasing moisture at $850 \mathrm{hPa}$, and increasing relative humidity at $700 \mathrm{hPa}$. The $K$ index is defined as follows (George 1960):

$$
\mathrm{KI}=\left(\mathrm{T}_{850}-\mathrm{T}_{500}\right)+\mathrm{T}_{\mathrm{d} 850}-\left(\mathrm{T}_{700}-\mathrm{T}_{\mathrm{d} 700}\right)\left[{ }^{\circ} \mathrm{C}\right]
$$

Severe Weather Threat Index incorporates kinematic and thermodynamic information. It assess low level moisture, convective environment, as well as wind shear and wind speeds as follows (Miller 1972):

$$
\begin{gathered}
\text { SWEAT }=12 \mathrm{~T}_{\mathrm{d} 850}+20(T \mathrm{~T}-49)+2 \mathrm{~V}_{850} \\
+\mathrm{V}_{500}+125\left(\sin \left(\mathrm{dd}_{500}-\mathrm{dd}_{850}\right)+0,2\right)
\end{gathered}
$$

where:

$T_{d 850}$ - is the dew point temperature at $850 \mathrm{hPa}$, TTI - is the Total Totals Index,
$V_{850}$ - is the $850 \mathrm{hPa}$ wind speed (in knots),

$\mathrm{V}_{500}$ - is the $500 \mathrm{hPa}$ wind speed (in knots),

the formula:

$\left(d d_{500}-d d_{850}\right)-$ describes the directional veering of wind with high.

CAPE, LI and SI are based on Lifted Parcel Theory, which represents the adiabatic lifting of a parcel in an environment described by radiosounding, while $T \mathrm{TI}, \mathrm{KI}$ and SWEAT are calculated by combined measurements of the thermal and moisture properties, as well as the wind shear in the low and mid-troposphere.

In order to identify days when no convective events were observed (such as thunderstorms, heavy precipitation or strong wind) despite the extreme values of instability indices, SYNOP reports from 6:00, 9:00, 12:00, 15:00 and 18:00 UTC (http://www.ogimet. $\mathrm{com} /$ ) were used. The weather data was limited to within $150 \mathrm{~km}$ of each upper air sensing station, i.e. 14 stations around Łeba, 15 around Legionowo and 16 around Wrocław (Fig. 1). The results were then verified using the European Severe Weather Database reports (http://www.eswd.eu/) and, in selected cases, also data from the lightning location system (http://www.lightningmaps.org, http://www. pogodynka.pl, http://www.wetterzentrale.de).

The study identified the following factors that may affect the development of vertical air movement: large scale mechanisms assisting in the development of convection (including fronts, convergence lines and low-pressure troughs), the occurrence of inhibition layers (isothermal and inversion), the presence of water vapour in ground-level layers, the lifting condensation level occurring at low altitude (the lower the value, the more conducive for convection), thermodynamic (measured with CAPE, $\mathrm{KI}, \mathrm{LI}, \mathrm{SWEAT}, \mathrm{SI}$ and TTI) and kinematic conditions (wind shears). The study was split into parallel sections covering the warm half of the year (April-September) and the cool half of the year (October-March). From each of these seasons one specific case where no powerful convective event was observed despite extremely high values of the indices was selected for detailed analysis. Archival MSL pressure maps 


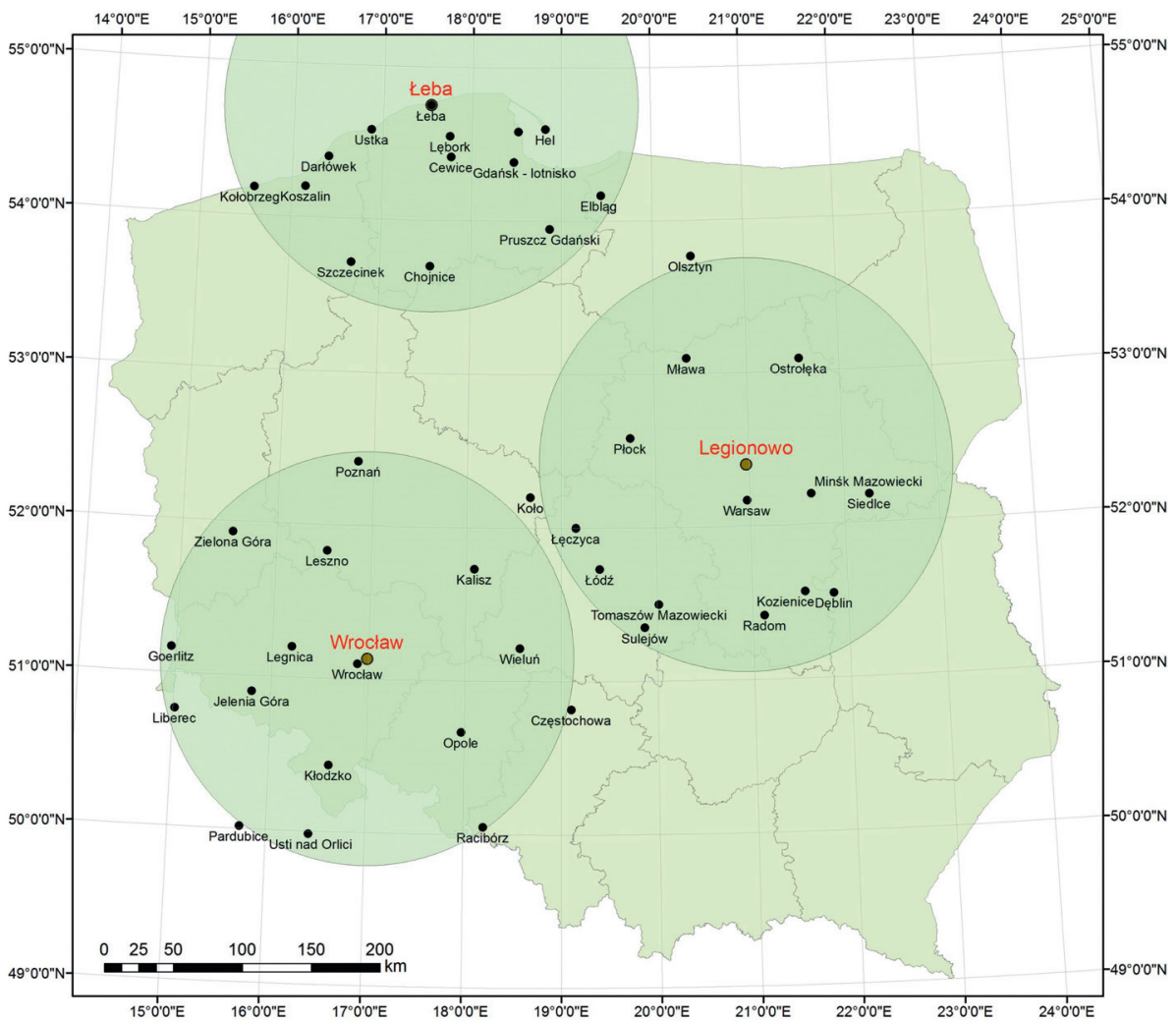

Figure 1. Location of upper air (red) and synoptic (black) stations used in the study

(http://www.knmi.nl/) were also used, as well as upper air maps at $850 \mathrm{hPa}$ and $500 \mathrm{hPa}$ (http://www.estofex.org, http://www.wetter3.de).

\section{Results}

\section{Mechanisms inhibiting convection in the warm season}

There were 14 cases altogether during the warm half of the year, with a clear majority in August. The largest number were recorded at the coastal station of Łeba (10) while the central station of Legionowo (3) and southwestern station of Wrocław (1) trailed well behind (Tab. 1). Such a wide spatial disparity was explained by a strong influence of the Baltic Sea, which not only promoted higher water vapour concentrations and higher wind speeds, but also promoted the advection of cooler air masses moving inland from over the sea, which potentially resulted in the development of isothermal and inversion layers in the boundary layer. Most of cases occurred in 2008 (3) and 2012 (5).

Isothermal and inversion layers in the lower and middle troposphere were found to have been the most frequent factors inhibiting vertical air movement. This effect was the strongest at Łeba where water vapour and the altitude of the lifting condensation level played a lesser role in inhibiting convection. These latter conditions proved more important in Legionowo and Wrocław. There, low water vapour concentrations in the boundary layer and high altitudes of the lifting condensation level provided strong barriers to the development of convection under extreme atmospheric instability conditions.

An analysis of synoptic conditions for selected cases showed that areas close to the 
Table 1. Convection inhibitors on selected days during the warm season

\begin{tabular}{|c|c|c|c|c|c|c|}
\hline $\begin{array}{l}\text { Date and place } \\
\text { of upper air } \\
\text { sounding }\end{array}$ & $\begin{array}{l}\text { Large-scale } \\
\text { convection } \\
\text { assisting } \\
\text { mechanisms }\end{array}$ & $\begin{array}{l}\text { Inhibitions } \\
\text { layers }\end{array}$ & $\begin{array}{l}\text { Humidity } \\
\text { at ground- } \\
\text { level }\end{array}$ & $\begin{array}{l}\text { Altitude } \\
\text { of conden- } \\
\text { sation level }\end{array}$ & $\begin{array}{l}\text { Kinematic } \\
\text { conditions }\end{array}$ & $\begin{array}{c}\text { Thermo- } \\
\text { dynamic } \\
\text { conditions } \\
\star \star \star\end{array}$ \\
\hline $\begin{array}{l}\text { Legionowo, } \\
8 \text { June } 2007\end{array}$ & - & - & - & - & - & $3 / 6$ \\
\hline $\begin{array}{l}\text { Legionowo, } \\
18 \text { June } 2012\end{array}$ & + & + & - & - & + & $3 / 6$ \\
\hline $\begin{array}{l}\text { Legionowo, } \\
11 \text { September } 2012\end{array}$ & - & - & - & - & - & $5 / 6$ \\
\hline $\begin{array}{l}\text { Łeba, } \\
5 \text { August } 2008\end{array}$ & + & + & + & + & + & $3 / 6$ \\
\hline $\begin{array}{l}\text { Łeba, } \\
12 \text { August } 2008\end{array}$ & - & - & + & + & + & $4 / 6$ \\
\hline $\begin{array}{l}\text { Łeba, } \\
6 \text { September } 2008\end{array}$ & - & - & + & $+/-$ & + & $3 / 6$ \\
\hline $\begin{array}{l}\text { Łeba, } \\
16 \text { July } 2010\end{array}$ & - & - & - & - & + & $3 / 6$ \\
\hline $\begin{array}{l}\text { Łeba, } \\
12 \text { August } 2010\end{array}$ & - & - & + & - & + & $4 / 6$ \\
\hline $\begin{array}{l}\text { Łeba, } \\
25 \text { August } 2011\end{array}$ & - & - & + & + & + & $3 / 6$ \\
\hline $\begin{array}{l}\text { Łeba, } \\
2 \text { June } 2012\end{array}$ & - & - & $+/-$ & + & - & $3 / 6$ \\
\hline $\begin{array}{l}\text { Łeba, } \\
2 \text { August } 2012\end{array}$ & - & - & - & - & + & $4 / 6$ \\
\hline $\begin{array}{l}\text { Łeba, } \\
10 \text { September } 2012\end{array}$ & - & - & - & - & - & $3 / 6$ \\
\hline $\begin{array}{l}\text { Łeba, } \\
31 \text { July } 2013\end{array}$ & + & - & + & + & + & $3 / 6$ \\
\hline $\begin{array}{l}\text { Wrocław, } \\
17 \text { August } 2006\end{array}$ & - & - & - & - & - & $3 / 6$ \\
\hline
\end{tabular}

Key: + Convection promoter, - Convection inhibitor

${ }^{\star *}$ Number of indices included with extreme values

upper air sensing stations were usually under the influence of high-pressure systems which blocked the movement of fronts and convergence lines. This means that area of Central Europe was free from the influence of largescale convection assisting mechanisms.

\section{Łeba, 2 August 2012}

On 2 August 2012, Central and Eastern Europe was under the influence of an extended anticyclone centred over Western Russia. The high-pressure system was blocking the eastward movement of a cyclone centred over the Eastern Atlantic, as well as ensured the advection of warm air masses from southeast. The area of Poland was unaffected by atmospheric fronts, convergence zones or low-pressure embayment that could be potentially conducive to the development of extensive convective systems (Fig. 2). Air temperature at ground level was very high with daily maximum above $30.0^{\circ} \mathrm{C}$ at most of the selected weather stations. Nevertheless, development of the cumulus clouds was limited due to relatively low humidity.

On this day, four of the six instability indices analysed in the study reached the defined extreme levels. The values of LI, SWEAT, KI and 


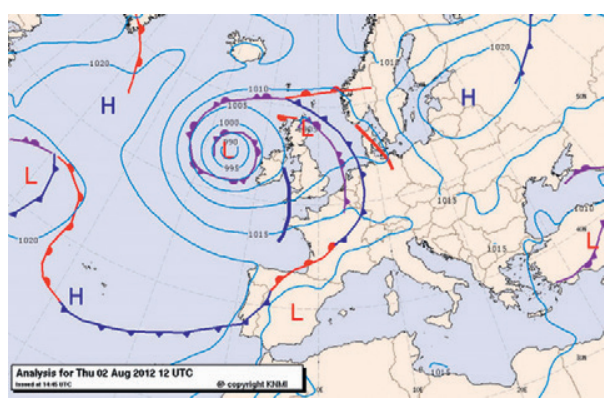

Figure 2. MSL pressure map, 2 August 2012, 12.00 UTC

Source: http://www.knmi.nl/klimatologie/daggegevens/weerkaarten/index.cgi.

CAPE suggested the possibility of the development of severe storms. It is worth mention that the value of SBCAPE, i.e. the convective available potential energy of an air parcel lifted from the surface, exceeded $1200 \mathrm{~J} / \mathrm{kg}$. The value of this parameter indicated the conditions conducive to the development of thunderstorms (Tab. 2). Despite the favorable conditions, the vertical air movement was inhibited and the severe convective phenomena did not occurr. It was mainly an effect of relatively high value of CIN ( $80 \mathrm{~J} / \mathrm{kg})$ (Fig. 3). The amount of energy that prevented the air parcel from rising from the surface to the level of free convection was associated with the relatively weak temperature gradient in the boundary layer, as well as strong temperature inversion occurring at the height of 3300-3700 m AGL. Moreover, the lack of large-scale mechanisms assisting convection and weak the downdrafts potential did not favor the dissipation of the inhibition layers. Two other factors that contributed to the inhibition of the development of convection included the low values of the kinematic indices, especially in the lower troposphere, and the relatively high altitude of the lifting condensation level.

\section{Legionowo, 11 September 2012}

On this day, Central Europe was under the influence of an anticyclone centred on the border between Ukraine and Russia and moving eastwards out of the area. Meanwhile, it was also blocking the eastward movement of a deep cyclone to the west of it (Fig. 4). A prefrontal convergence zone linked to that cyclone carried on slowly and only arrived in the central-Polish region of Mazovia at about 3:00 UTC on 12 September. This meant that on the previous day, central Poland was free from

Table 2. The values of the instability indices

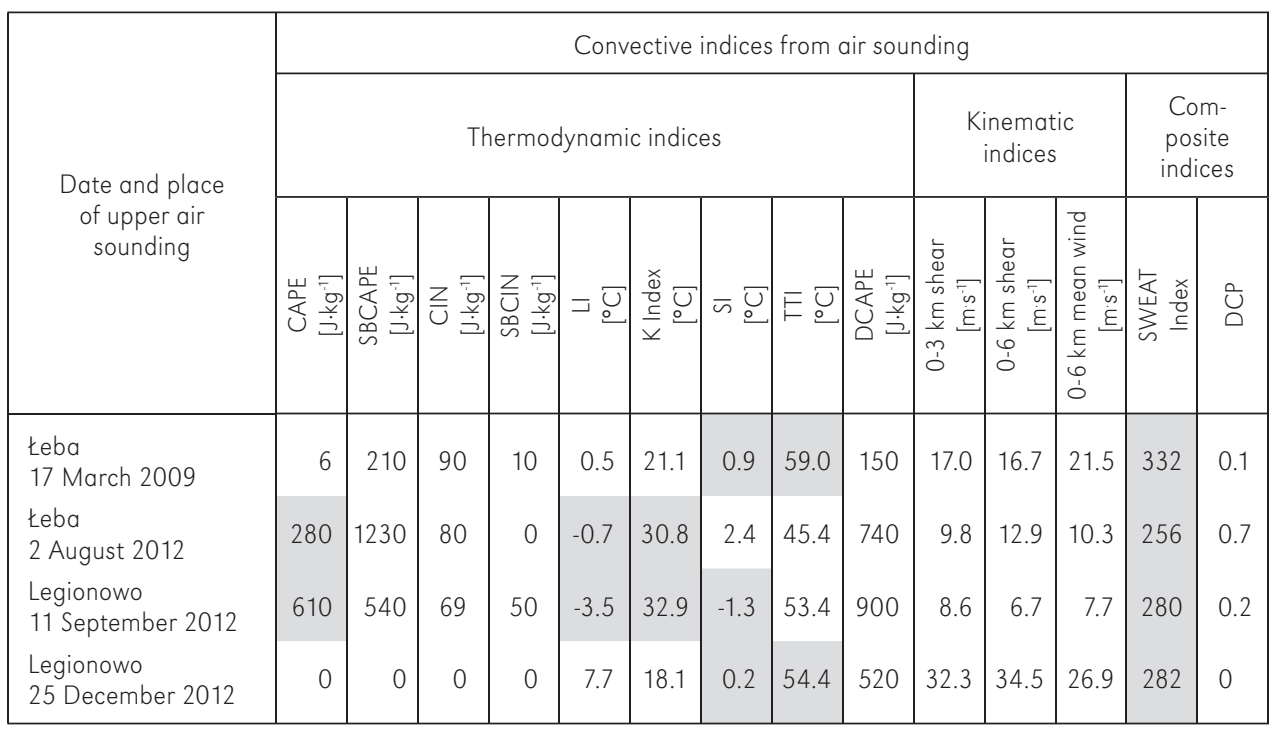




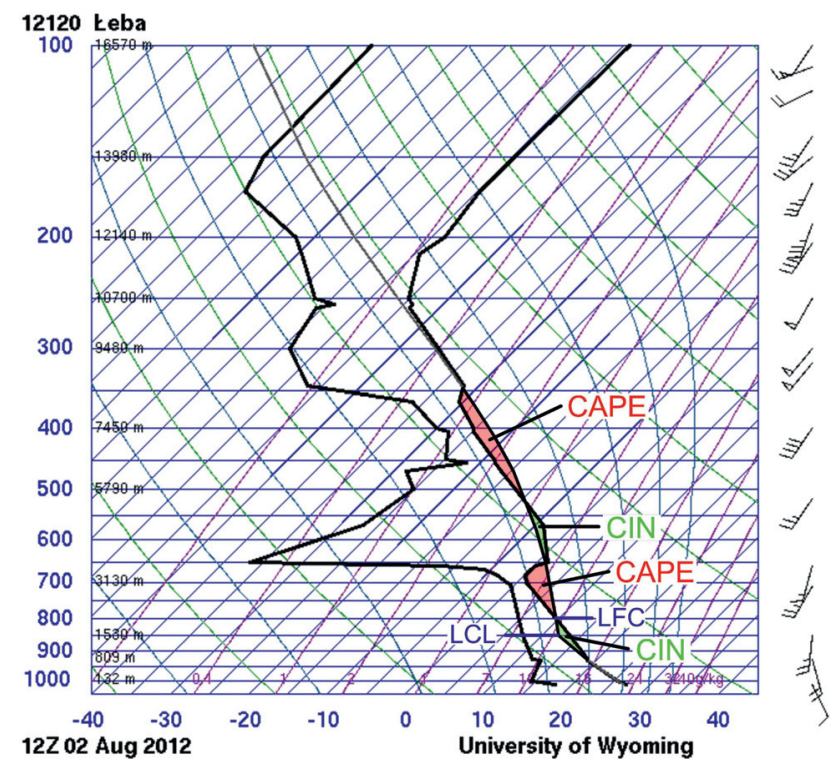

Figure 3. Upper air sounding plot, 2 August 2012, Łeba, 12:00 UTC Source: http://weather.uwyo.edu/upperair/sounding.html.

the influence of large-scale convection assisting mechanisms. However, air temperature was very high with the daily maximum ranging between $28.0^{\circ} \mathrm{C}$ and $31.0^{\circ} \mathrm{C}$, which could potentially help the development of thunderstorm cells. Nevertheless, convection development was arrested due to very low humidity that did not exceed $40 \%$ between 12:00 and 15:00 UTC.

All of the atmospheric instability indices included in the study were characterised

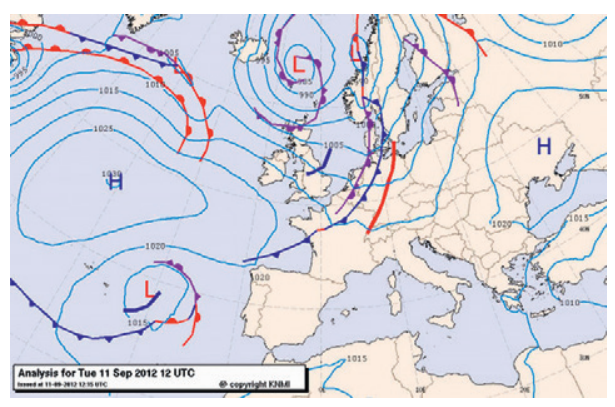

Figure 4. MSL pressure map, 11 September 2012, 12.00 UTC

Source: http://www.knmi.nl/klimatologie/daggegevens/weerkaarten/index.cgi. by relatively high values with the exception of $\Pi \mathrm{T}$, which failed to reach the defined extreme levels, but even this index suggested a potential for scattered severe storms. Other indices provided information about considerable levels of convective available potential energy (CAPE) and a high likelihood of extensive convective systems ( $\mathrm{K}$ Index). Also the LI and SI recorded values well below zero suggesting high levels of instability in the lower troposphere. Additionally, SBCAPE (Surface Base Convective Available Potential Energy) and DCAPE (Downdraft Convective Available Potential Energy) displayed high values suggesting conditions conducive to the development of strong downdrafts (Tab. 2).

Two other factors that contributed to the inhibition of the development of a powerful convection process included the occurrence, at $1500 \mathrm{~m}$ - $1800 \mathrm{~m}$, of an isothermal layer, and an advection of relatively dry air in the lower troposphere (Fig. 5). As a consequence, there was considerable energy inhibiting convection with a CIN of up to $70 \mathrm{~J} / \mathrm{kg}$. The value of CIN would be higher, if the inversion layer occurred in the lower troposphere. 


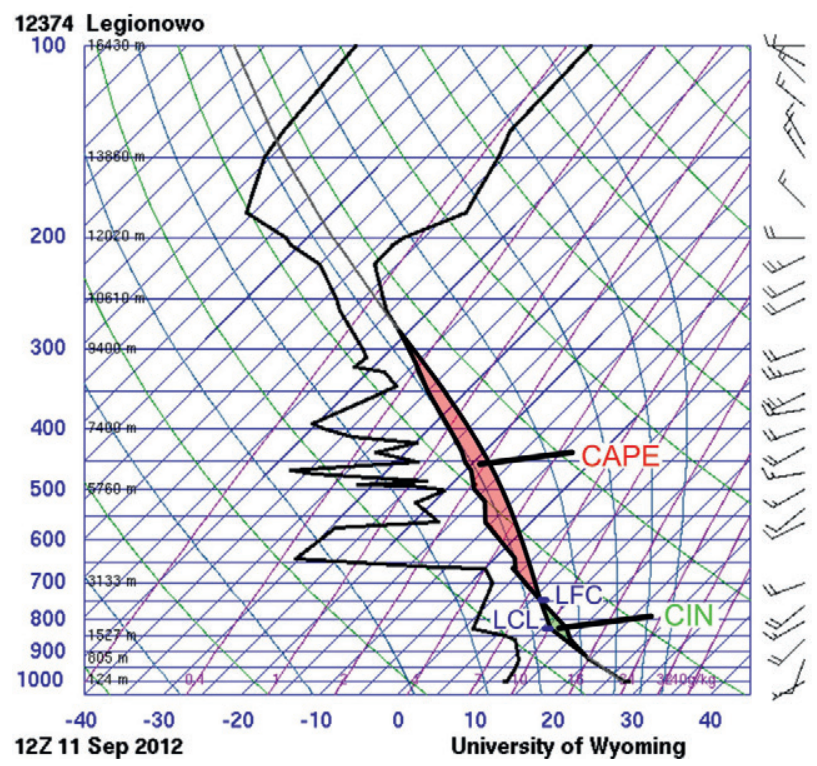

Figure 5. Upper air sounding plot, 11 September 2012, Legionowo, 12:00 UTC Source: http://weather.uwyo.edu/upperair/sounding.html.

Additionally the relatively high altitude of the lifting condensation level $(2000 \mathrm{~m})$ and its relatively large separation from the level of free convection effectively prevented a buildup of cumulus clouds and, consequently, of thunderstorm cells. Low values of kinematic indices proved insufficient for the inhibiting layer to dissipate.

\section{Mechanisms inhibiting convection in the cool season}

There were 12 cases studied altogether during the cool half of the year, with a majority concentrated in December and January. Just as during warm season, Łeba had the largest number of them (7) with slightly lower numbers at Legionowo (4) and Wrocław (1) (Tab. 3).

The most frequent factors inhibiting upward air movement at all three stations were isothermal and inversion layers. Both the water vapour concentration and the kinematic conditions had a potentially positive influence on the development of convection on the days selected.
In the cool season, the effect of a lack of large-scale mechanisms assisting convection was less frequent than in the warm part of the year. In the days when no convective events were observed despite the extreme values of instability indices, Poland was usually under the influence of high-pressure systems centred over eastern Europe. Such pressure systems blocked the movement of atmospheric fronts. Additionally, the vast warm areas of low-pressure systems moving across northern Europe played significant role.

\section{Łeba, 17 March 2009}

On 17 March 2009, Poland and Baltic States were under the influence of a lowpressure embayment, within which the secondary depression developed. The depression centre was located over the Baltic Sea, near the Polish and Lithuanian coastline. Simultaneously, a vast anticyclone occurred over the British Isles. The distribution of the pressure systems caused the occurrence of strong pressure gradient over the Central Europe and promoted an advection of cold air mass from the north part of the continent over the 
Table 3. Convection factors on selected days during the cool season

\begin{tabular}{|c|c|c|c|c|c|c|}
\hline $\begin{array}{l}\text { Date and place } \\
\text { of upper air sounding }\end{array}$ & $\begin{array}{c}\text { Large-scale } \\
\text { convection } \\
\text { assisting } \\
\text { mecha- } \\
\text { nisms }\end{array}$ & $\begin{array}{l}\text { Inhibitions } \\
\text { layers }\end{array}$ & $\begin{array}{l}\text { Humidity } \\
\text { at ground- } \\
\text { level }\end{array}$ & $\begin{array}{l}\text { Altitude } \\
\text { of conden- } \\
\text { sation level }\end{array}$ & $\begin{array}{l}\text { Kinematic } \\
\text { conditions }\end{array}$ & $\begin{array}{c}\text { Thermo- } \\
\text { dynamic } \\
\text { conditions } \\
\star \star\end{array}$ \\
\hline $\begin{array}{l}\text { Legionowo, } \\
7 \text { October } 2009\end{array}$ & + & - & + & + & + & $4 / 6$ \\
\hline $\begin{array}{l}\text { Legionowo, } \\
4 \text { October } 2011\end{array}$ & & - & - & & + & $4 / 6$ \\
\hline $\begin{array}{l}\text { Legionowo, } \\
25 \text { December } 2012\end{array}$ & & & + & $+/-$ & + & $3 / 6$ \\
\hline $\begin{array}{l}\text { Legionowo, } \\
8 \text { stycznia } 2014\end{array}$ & - & - & + & + & + & $3 / 6$ \\
\hline $\begin{array}{l}\text { Łeba, } \\
13 \text { stycznia } 2005\end{array}$ & - & + & + & + & - & $3 / 6$ \\
\hline $\begin{array}{l}\text { Łeba, } \\
21 \text { October } 2006\end{array}$ & & - & + & + & - & $3 / 6$ \\
\hline $\begin{array}{l}\text { Łeba, } \\
1 \text { stycznia } 2007\end{array}$ & + & - & + & + & + & $3 / 6$ \\
\hline $\begin{array}{l}\text { Łeba, } \\
2 \text { grudnia } 2007\end{array}$ & - & + & + & + & + & $3 / 6$ \\
\hline $\begin{array}{l}\text { Łeba, } \\
17 \text { marca } 2009\end{array}$ & + & - & + & + & + & $3 / 6$ \\
\hline $\begin{array}{l}\text { Łeba, } \\
4 \text { stycznia } 2012\end{array}$ & - & - & + & + & + & $3 / 6$ \\
\hline $\begin{array}{l}\text { Łeba, } \\
2 \text { stycznia } 2013\end{array}$ & + & - & + & + & - & $3 / 6$ \\
\hline $\begin{array}{l}\text { Wrocław, } \\
1 \text { grudnia } 2008\end{array}$ & - & - & + & + & + & $3 / 6$ \\
\hline
\end{tabular}

Key: + Convection promoter, - Convection inhibitor

$\star \star$ Number of indices included with extreme values

Pomerania (Fig. 6). The values of the wind speed on different isobaric levels were characterised by a strong heterogeneity, which in turn led to the high values of wind shear exceeding $15 \mathrm{~m} / \mathrm{s}$.

On this day, three of the atmospheric instability indices (SI, SWEAT and KI) were characterised by the defined extreme values. However it is worth adding that the value of $\mathrm{SI}$ reaching $0.9^{\circ} \mathrm{C}$ suggested low level of instability in the troposphere. Additionally, SBCAPE with the value above $200 \mathrm{~J} / \mathrm{kg}$, provided information about the possibility of development of the quite strong vertical movement

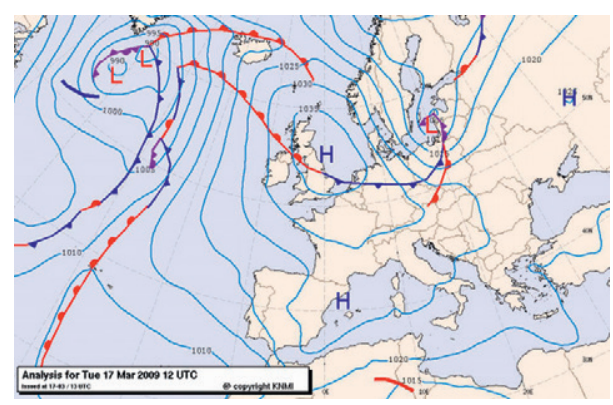

Figure 6. MSL pressure map, 17 March 2009, 12.00 UTC

Source: http://www.knmi.nl/klimatologie/daggegevens/weerkaarten/index.cgi. 


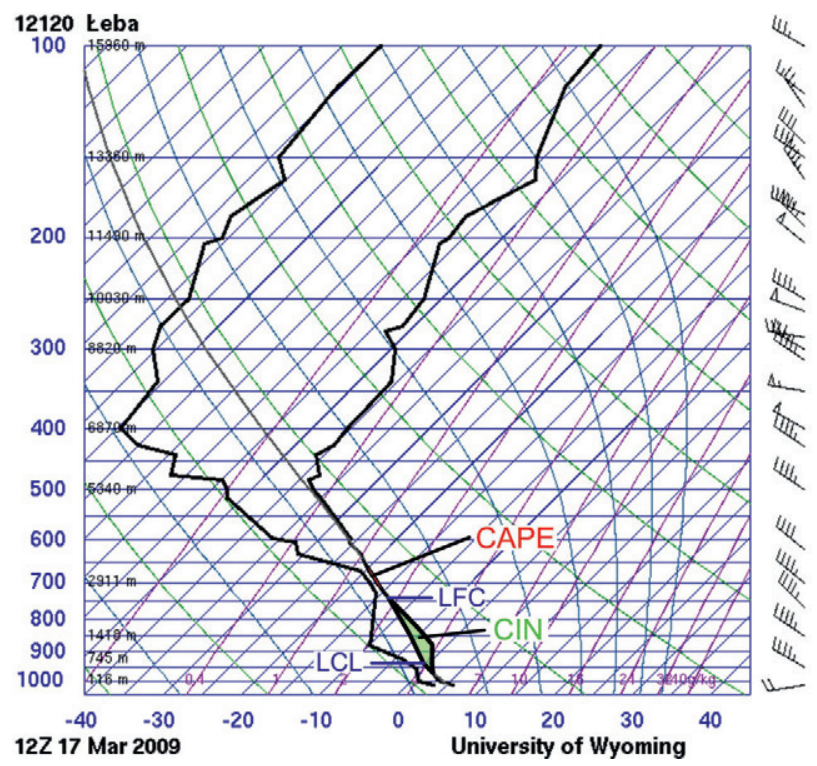

Figure 7. Upper air sounding plot, 17 March 2009, Łeba, 12:00 UTC Source: http://weather.uwyo.edu/upperair/sounding.html.

of air (Tab. 2). The development of the upward movement of air was inhibited by high value of CIN $(90 \mathrm{~J} / \mathrm{kg})$ (Fig. 7). Also, the relatively high altitude of the lifting condensation level and its large separation from the level of free convection played an important role in prevention of the cumulus clouds expansion.

\section{Legionowo, 25 December 2012}

On this day, Central Europe was within the warm area of a multicentre cyclone with its centres over the Baltic Sea and the North Sea (Fig. 8). Central Poland was unaffected by atmospheric fronts or convergence zones, both potentially acting to impede the development of the upward movement of air. The distribution of the pressure systems and its associated significant pressure gradient promoted an advection of warm and humid air from the southwest and west. Despite this being mid-December, the temperatures in central Poland exceeded $10^{\circ} \mathrm{C}$ with daily maximum $10.5^{\circ} \mathrm{C}$ in Płock and $10.3^{\circ} \mathrm{C}$ in Łódź, while relative humidity was much greater than $80 \%$. Both of these conditions potentially promoted the development of convective air movement.
This was also helped by high flow-rates in all layers of the troposphere manifested by considerable wind shears $(0-3 \mathrm{~km}$ shear and 0-6 km shear) and mean wind rates (0-6 km mean wind) (Tab. 2). High wind shears are known to ensure good separation between updraft and downdraft and allow the development of extensive convective systems (destructive squall lines) in the cool season even in conditions of very low thermodynamic instability.

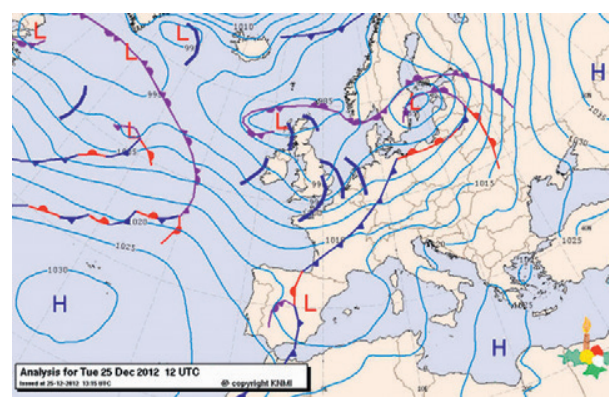

Figure 8. MSL pressure map, 25 December 2012, 12.00 UTC

Source: http://www.knmi.nl/klimatologie/daggegevens/weerkaarten/index.cgi. 


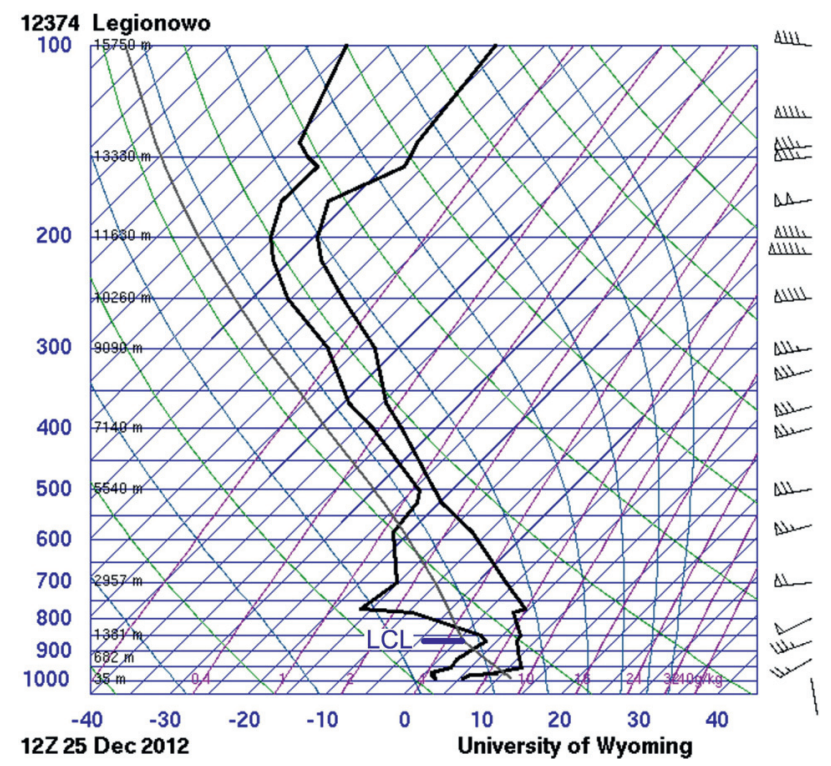

Figure 9. Upper air sounding plot, 25 December 2012, Legionowo, 12:00 UTC Source: http://weather.uwyo.edu/upperair/sounding.html.

Despite considerable TTI and SWEAT values, the development of convection was inhibited and this was mainly an effect of two inversion layers (Fig. 9). In accordance with the soundings performed at Legionowo one of these layers, positioned at ground level, had a thickness of $450 \mathrm{~m}$ and high strength of $10^{\circ} \mathrm{C}$ while the other was in the free atmosphere $(1800 \mathrm{~m})$ and had a strength of ca. $2^{\circ} \mathrm{C}$. Indeed, this strength would have been sufficient to inhibit convection even at much higher values of the indices included in the study.

\section{Summary and conclusions}

The analysis of the selected cases has demonstrated that the inhibition of vertical air movement under extreme atmospheric instability was principally caused by the occurrence of inhibition layers, i.e. isothermal or inversion layers in the lower and middle troposphere. This effect prevailed both in the warm and cool half of the year. The presence of isothermal and inversion layers led to increase the amount of energy that prevented an air parcel from rising from the surface to the level of free convection. The CIN values often reached approximately $80 \mathrm{~J} / \mathrm{kg}$, particularly during the warm season. As it is shown in the research conducted by Khodayar et al. (2010), CIN and convergence may play more important role in the convection development than high CAPE values. Convection was also impeded by the location of the study area beyond the effect of large-scale assisting mechanisms, i.e. atmospheric fronts and convergence zones. Poland was often under the influence of the high-pressure systems centred over eastern Europe or within the vast warm areas of lowpressure systems moving across northern Europe.

The contribution of the various inhibiting factors varied from season to season. During the warm season, low water vapour concentrations and high altitudes of the level of free convection (LFC) and the lifting condensation level (LCL) played a much greater role. Drier environment leads to stronger evaporative cooling and negative buoyancy (Debryshire et al. 2004). The low humidity as well as the high altitude of the lifting condensation level and its large separation from the level of free 
convection effectively prevented a buildup of cumulus clouds and consequently of thunderstorm cells. Stirling and Petch (2004) pointed out that the variability of relative humidity in the boundary layer has also important influence on local convective inhibition. Moreover, they suggested that the deep convection timing depends on the maximum value of relative humidity at the beginning of the day.

The records from the air sounding stations allowed the identification of a strong spatial variability. This was mainly linked to the nature of the active surface in the vicinity of the station. It played the most significant role at Łeba and in the northern-Polish region of Pomerania, where it was associated with the strong influence of the Baltic Sea affecting the higher water vapour concentrations and wind speeds as well as the advection of cooler air masses moving inland from over the sea.

The analysis showed that the use of selected stability indices can be limited in particular cases. For example SWEAT index, which was especially dedicated for US Great Plains

\section{References}

Bentley M.L., Mote T.L., 2000. A synoptic climatology of cool-season derecho events. Physical Geography, vol. 21, no. 1, pp. 21-37.

BlanCHARD D.O., 1998. Assessing the vertical distribution of Convective Available Potential Energy. Weather and Forecasting, vol. 13, no. 3, pp. 870-877.

BROOKS H.E., 2009. Proximity soundings for severe convection for Europe and the United States from reanalysis data. Atmospheric Research, vol. 93, no. 1-3, pp. 546-553.

Brooks H.E., Anderson A.R., Riemann K., Ebbers I., Flachs H., 2007. Climatological aspects of convective parameters from the NCAR/ NCEP reanalysis. Atmospheric Research, vol. 83, no. 2, pp. 294-305.

Brooks H.E., Lee J.W., Craven J.P., 2003. The spatial distribution of severe thunderstorm and tornado environments from global reanalysis data. Atmospheric Research, vol. 67-68, pp. 73-94. events, can be problematic in European conditions. As is shown in the study of Siedlecki (2009), SWEAT index is good for measuring atmospheric instability, while the values of CAPE and $\mathrm{KI}$ indices may be lower. However, during the cool seasons in Europe, the monthly means of SWEAT are increased and the assessment of instability could be wrong. It should be also pointed out, that the use of other stability indices in the cool season can be also limited. This is due to the fact that convective events are the most often connected with frontal systems (mostly cold fronts), rarely occur within polarmaritime air masses to the rear of frontal systems or convergence zone. Additionally, the kinematic conditions play more important role in development of convection (eg. high values of vertical shears), than thermodynamic ones.

\section{Editors' note:}

Unless otherwise stated, the sources of tables and figures are the authors', on the basis of their own research.

BURKE P.C., SChultz D.M., 2004. A 4-yr climatology of cold-season bow echoes over the continental United States. Weather and Forecasting, vol. 19, no. 6, pp. 1061-1073.

Chaboureau J.-P., Guichard F., Redelsperger J.-L., LAFORE J.-P., 2004. The role of stability and moisture in the diurnal cycle of convection over land. Quarterly Journal of the Royal Meteorological Society, vol. 130, no. 604, pp. 3105-3117.

DAVIES J.M., 2004. Estimations of CIN and LFC associated with tornadic and nontornadic supercells. Weather and Forecasting, vol. 19, no. 4, pp. 714-726.

Derbyshire S.H., Beau I., Bechtold P., GrandPeiX J.P., Piriou J.M., Redelspreger J.L., SoARES P.M. M., 2004. Sensitivity of moist convection to environmental humidity. Quarterly Journal of the Royal Meteorological Society, vol 130, pp. 3055-3080.

DERUBERTIS D., 2006. Recent trends in four common stability indices derived from U.S. radiosonde 
observations. Journal of Climate, vol. 19, no. 3, pp. 309-323.

GALWAY J.G., 1956. The lifted index as a predictor of latent instability. Bulletin of the American Meteorological Society, vol. 37, pp. 528-529.

GeORGE J.J., 1960. Weather forecasting for aeronautics. New York-London: Academic Press.

Gubenko I.M., Rubinshtein K.G., 2015. Analysis of the results of thunderstorm forecasting based on atmospheric instability indices using the WRFARW numerical model data. Russian Meteorology and Hydrology, vol. 40, no. 1, pp. 16-24.

Hand W.H., Cappeluttı G., 2011. A global hail climatology using the UK Met Office convection diagnosis procedure (CDP) and model analyses. Meteorological Applications, vol. 18, no. 4, pp. 446-458.

Khodayar S., Kalthoff N., Wickert J., Cormeler U., Morcrette C.J., Kottmeier C., 2010. The increase of spatial data resolution for the detection of the initiation of convection. A case study from CSIP. Meteorologische Zeitschrift, vol. 19, no. 2, pp. 179-198.

Millek R.C., 1972. Notes on analysis and severestorm forecasting procedures of the Air Force Global Weather Central. Scott Air Force Base, IL.

MonCRieff M.W., Miller M.J., 1976. The dynamics and simulation of tropical cumulonimbus and squall-lines. Quarterly Journal of the Royal Meteorological Society, vol. 102, no. 432, pp. 373-394.

Palencia C., Gialotti D., Stel F., Castro A., Fralle R., 2010. Maximum hailstone size: Relationship with meteorological variables. Atmospheric Research, vol. 96, no. 2-3, pp. 256-265.

Riemann-Campe K., Fraedrich K., Lunkeit F., 2009. Global climatology of Convective Available Potential Energy (CAPE) and Convective Inhibition (CIN) in ERA-40 reanalysis. Atmospheric Research, vol. 93, no. 1-3, pp. 534-545.
Romero R., Gaya M., Doswell C.A., 2007. European climatology of severe convective storm environmental parameters: A test for significant tornado events. Atmospheric Research, vol. 83, no. 2-4, pp. 389-404.

Sanchez J.L., Marcos J.L., Dessens J., Lopez L., Bustos C., Garcia-Ortega E., 2009. Assessing sounding-derived parameters as storm predictors in different latitudes. Atmospheric Research, vol. 93, no. 1-3, pp. 446-456.

Sherburn K.D., Parker M.D., 2014. Climatology and ingredients of significant severe convection in High-Shear, Low-CAPE environments. Weather and Forecasting, vol. 29, no. 4, pp. 854-877.

SHOWAlter A.K., 1953. A stability index for thunderstorm forecasting. Bulletin of the American Meteorological Society, vol. 34, no. 6, pp. 250-252.

SiedleCKI M., 2009. Selected instability indices in Europe. Theoretical and Applied Climatology, vol. 96, no. 1-2, pp. 85-94.

Stirling A.J., PetCH J.C., 2004. The impacts of spatial variability on the development of convection. Quarterly Journal of the Royal Meteorological Society, vol. 130, pp. 3189-3206.

Van Den Broeke M.S., Schultz D.M., Johns R.H., Evans J.S., Hales J.E., 2005. Cloud-to-ground lighting production in strongly forced, low instability convective lines associated with damaging wind. Weather and Forecasting, vol. 20, no. 4, pp. 517-530.

Venkat Ratnam M., Durga Santhi Y., Raueevan M., VIJAYA Bhaskara RaO S., 2013. Diurnal variability of stability indices observed using radiosonde observations over a tropical station: Comparison with microwave radiometer measurements. Atmospheric Research, vol. 124, no. 4, pp. 21-33.

Wong S., DesSLer A.E., 2005. Suppression of deep convection over the tropical North Atlantic by the Saharian Air Layer. Geophysical Research Letters, vol. 32, no. 9, pp. 1-4. 